\title{
A Survey of the Flora and Fauna of Mangrove Forests in Bachok, Kelantan, Malaysia
}

\author{
Sasekumar A.* and H. H. Moh \\ Institute of Biological Sciences, Faculty of Science, University of Malaya, 50603 Kuala Lumpur \\ *sasekumarga@live.com.my (Corresponding author) \\ Received on $2^{\text {nd }}$ July 2009, accepted in revised form $24^{\text {th }}$ November 2009.
}

\begin{abstract}
The flora and fauna of mangrove forests in nine localities in Bachok, Kelantan were investigated from $16^{\text {th }}$ to $19^{\text {th }}$ June 2008. Though much of the mangroves have been reclaimed, remnant mangroves were found in the estuary of Semerak River. Nypa fruticans colonized the banks of the estuary, while Rhizophora apiculata dominated much of the upper shore. Elsewhere, there were small stands of Sonneratia alba, Avicennia marina and Bruguiera spp. The benthic fauna was dominated by 18 species of gastropods, 5 species of bivalves, 13 species of crustaceans (mostly sesarmine crabs), a sipuncula and 3 species of small fishes. East coast mangroves are estuarine in nature as they are located in sheltered situations, and thus not subjected to strong wave action or tidal currents. Accumulation of leaf litter on the forest floor seems to have encouraged high numbers of detritus feeding gastropod, Neritina violacea, to flourish in the high shore mangrove forest.
\end{abstract}

ABSTRAK Flora dan fauna hutan bakau telah dikaji di 9 lokasi di Bachok, Kelantan dari 16hb sehingga 19hb June 2008. Walaupun sebahagian besar hutan bakau dalam daerah Bachok telah musnah akibat diterokai, masih terdapat saki-baki hutan didapati di Kuala Sungai Semerak. Nypa fruticans dijumpai pada tebing kuala, manakala Rhizophora apiculata tumbuh di kawasan tinggi di hutan bakau tersebut. Di kawasan lain pada kuala tersebut, terdapat pokok lain seperti Sonneratia alba, Avicennia marina dan Bruguiera spp. Fauna bentik didominasi oleh 18 spesies gastropoda, 5 spesies bivalvia, 13 spesies krustacea (terutama ketam), sejenis sipuncula, dan 3 spesies ikan.kecil. Hutan bakau di pantai timur terletak di kawasan kuala yang terlindung, dari ombak kuat. Timbunan daundaun pada sediment hutan bakau telah menyebabkan bilangan gastropod Neritina violacea yang tinggi. Ia bergantung pada daun yang reput sebagai bahan makanan.

(Keywords: mangroves, benthic fauna, gastropods, bivalves, sesarmid crabs, sipuncula)

\section{INTRODUCTION}

The shores of the east coast of Peninsular Malaysia are generally sandy and attractive for beach recreational activities. However, all estuaries on the east coast are mud dominated estuaries, endowed with mangrove forests. Protection from strong wave action provides for deposition of sediments, and subsequent growth of mangrove vegetation. Gong et al. [1] noted the presence of mangroves in Kelantan, though with limited cover in areas such as Gali, Pengkalan Chepa, Kuala Sungai (Sg.) Kemasin, Merang and Besar Keluang. However, the authors noted more extensive cover of mangroves in $\mathrm{Sg}$. Golok, Pengkalan Datu, Kuala Sg. Semerak, Besut and Setiu, but no figures of area cover were provided. There appears to be large area of mangroves in the islands of the Sg. Kelantan Delta, east of Tumpat [2]. There is also extensive growth of Nypa fruticans along the banks of the Sg. Golok.

Survey of mangrove invertebrates on the east coast of peninsular Malaysia was carried out by Wong et al.
[3]. However, they only surveyed Sg. Setiu and Sg. Merang in Kelantan, and recorded 16 species of benthic invertebrates in forests dominated by Nypa and "mixed mangroves". The focus of their study was the mangroves located in Terengganu, Pahang and Johore.

According to the Kelantan State Department of Forestry [4] there are only 744 ha of mangroves in Kelantan, mainly confined to the estuaries of Semerak, Pasir Putih and Tumpat. The forest is under the management of the State Forest Department. However, a recent official letter from the Kelantan state Forest Department states that there are only 6 ha of mangroves in Kuala Semerak and none in Kuala Kemasin. The same letter states that most of the mangrove forests had been alienated to residents staying nearby. It appears that the existence of an important coastal resource such as mangroves within Kelantan has not been documented! A similar conclusion was reached by Latiff [5]. 
Ground surveys during this study showed there are remnant areas of mangroves along the shores of the $\mathrm{Sg}$. Semerak estuary though large areas have been destroyed in the channeling of the estuary. Mangroves in Sg. Kemasin have been reclaimed for aquaculture of tiger prawns and only a few trees remain scattered along its river banks. The estuary of the Sg. Semerak has a large water body where floating cage culture of estuarine fish like sea bass and groupers is being carried out on a large scale. Local fishermen reported that fish production is poor, probably as a result of poor management and or impact of high freshwater flow during the north-east monsoon.

\section{Mangrove Macrobenthos}

Mangrove Macrobenthos are animals from phyla such as Annelida (polychaeta), Mollusca (gastropoda), Arthropoda (crustacea) and Sipuncula that live on or within substrates. These are marine invertebrates which have evolved to live in the intertidal sector of the sea and have the ability to respire in air or water or both.

\section{METHODS}

Mangroves in the estuaries of major rivers in the Bachok District, Kelantan, were surveyed by boat and foot from the $16^{\text {th }}$ to $19^{\text {th }}$ June 2008 . We walked into the mangroves from the landside to collect fauna especially gastropods and crustaceans either by digging with a spade or picking from the substrate surface. Thus, the data presented here represents qualitative samples where visible animals were collected. Abundance is indicated by the number of asterisk: * = rare (when one specimen was observed); $* *=$ common $(2-3$ specimens observed $) ; * *$ = very common (4 or more specimens observed).

\section{RESULTS}

\section{Site 1: Sg. Semerak}

The site is located near Kg. Katil Buloh (Figure 1). Nypa fruticans was very common in this locality, but partly cleared for cattle farming. There were few Avicennia alba trees and as well as fern Acrostichium aureum was also present. R.hizophora apiculata was the abundant vegetation. The patch of forest is about 15 years old with an average height of six metres. Also observed was Derris trifoliata, the climber and Thalassina mounds. The substrate was soft with brown mud and abundance of decomposing leaves. The salinity of the water in puddles was $13 \mathrm{ppt}$.

This site being on the high mangrove shore had abundance of litter on the forest floor. The gastropods
Neritina violacea, Melampus sp. and Sesarminae crabs were common (Table 1).

\section{Site 2: Kg. Katil Buluh}

The site had pure stands of $10-15$ metre tall $R$. apiculata that covered an extensive area which seems to be under sustainable management as the trees were of similar height. The substrate was soft and dark brown with many mud lobster Thalassina mounds. The abundant gastropods here were Assiminea brevicula, Neritina violacea, Cerithidea quadrata, Cassidula aurisfelis, Melampus sp. and the bivalve Geloina erosa (Table 1).

\section{Site 3: (near bridge, Figure1)}

The common invertebrates were saddle oyster (Enigmonia aenigmatica, Plate 1) and mussel Mytilus viridis (kupang). They were found growing on tree trunks of mangrove trees including Nypa fruticans found on river banks (Table 1).

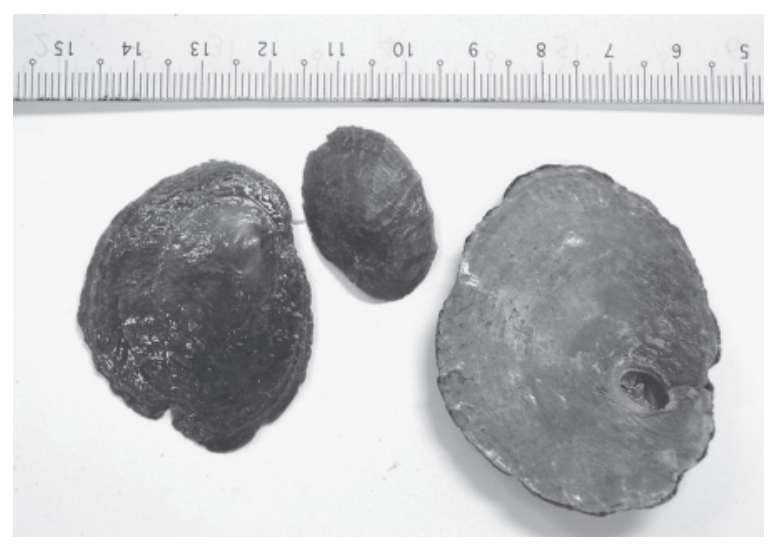

Plate 1. Dorsal (left) and ventral view (right) of saddle oyster, Enigmonia aenigmatica.

\section{Site 4: Lagoon near seafront (Figure 1)}

The site is located near Kg. Pasir Sotong. The lagoon was formed after closing of the original river mouth of Sg. Semarak.

Many seedlings of Sonneratia alba and few Avicennia marina were found growing in the sheltered lagoon waters. Trees were not more than five metres tall. The seafront was approximately 200 metres east of this site. Tall trees of Casuarina equistifolia faced the sea front. Salinity of the estuarine water was $20 \mathrm{ppt}$.

There was an abundance of fauna in the small area colonized by mangrove vegetation. The common gastropods were Littoraria spp., Cerithidea cingulata, Clithon oualeniensis, and crab Perisesarma eumolpe. Barnacles were abundant and attached to tree trunks and pneumatophores. 
Table 1: Distribution of fauna in mangroves of Bachok District, Kelantan (June 2008).

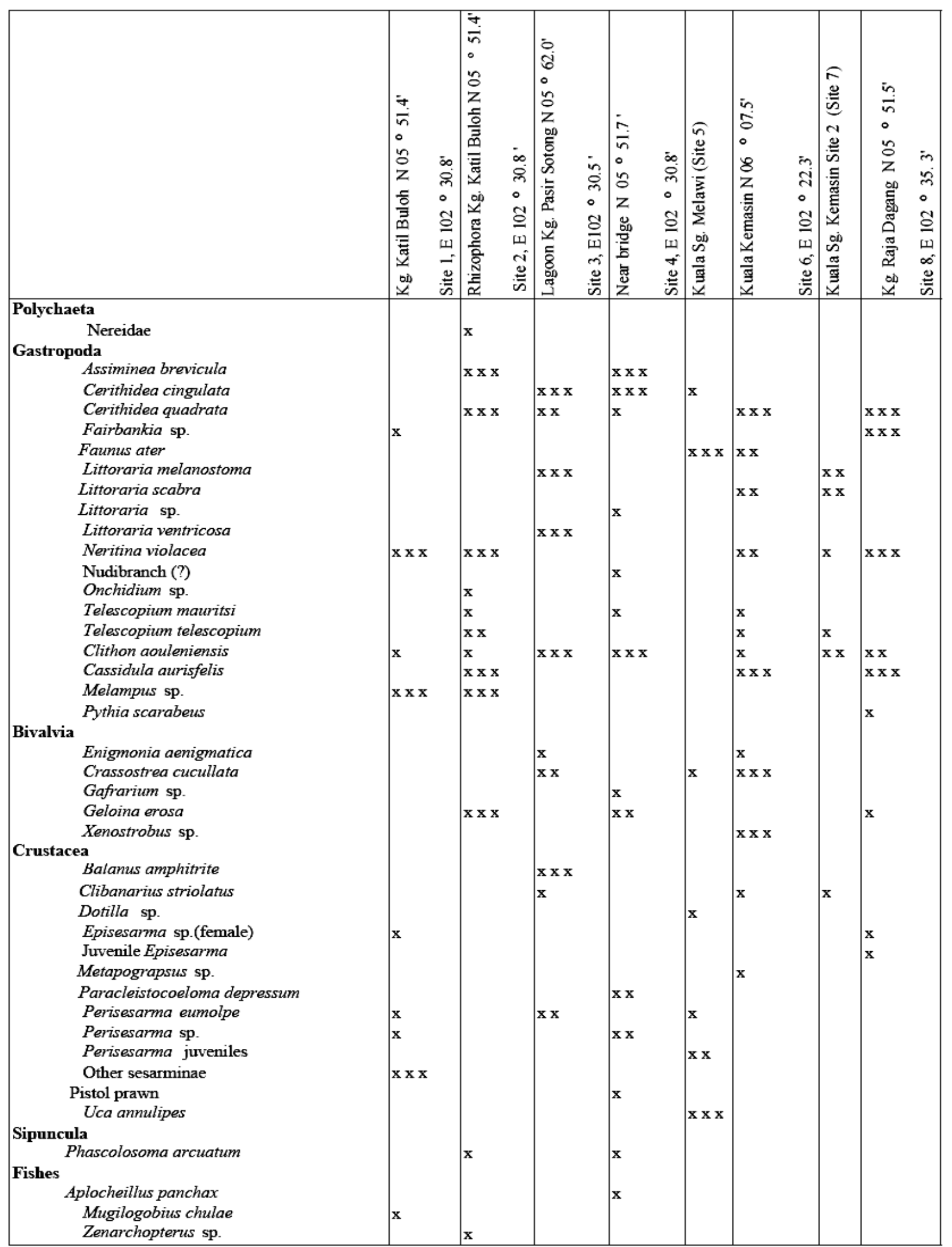

$\mathrm{x}=$ rare, $\mathrm{xx}=$ common, $\mathrm{xxx}=$ very common 


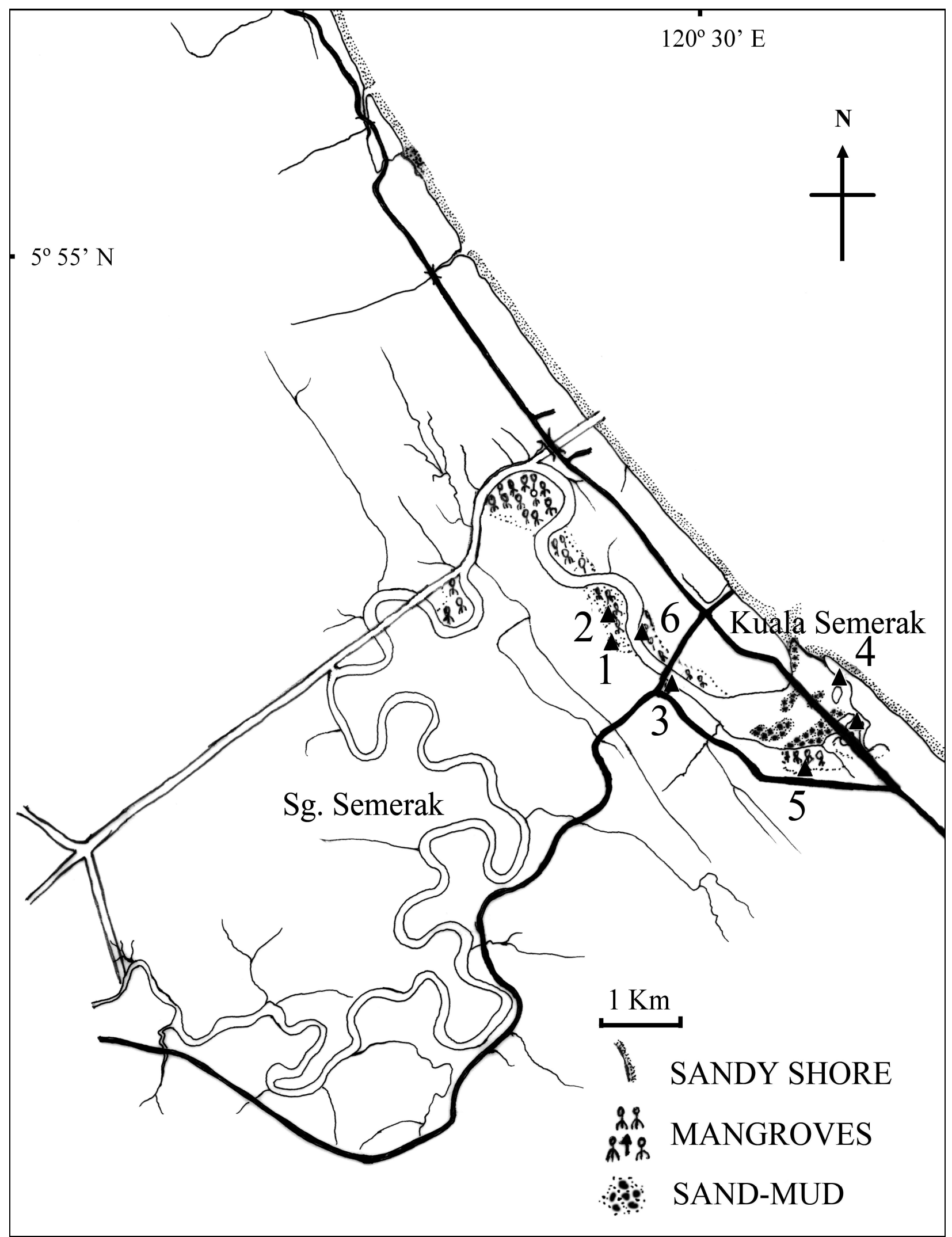

Figure 1. Distribution of mangrove forests in the estuary of Sg. Semerak, Kelantan. Sampling for macrofauna was carried out in sites 1 to 6 during June 2008. 
Site 5: Site 2 (Figure 1)

The vegetation was dominated by Avicennia alba and Sonneratia alba whose extensive pneumatophores provided some firmness to the substrate for walking. There were a few Bruguiera away from the channel.

The common benthic animals were gastropods $C$. cingulata, Clithon oualeniensis, Neritina violacea and sipuncula Phascolosoma arcuatum, and a few grapsid crabs (Table 1). The bivalve Geloina erosa was common on the forest floor. We noted the presence of pistol prawns along the soft channel banks, but only one specimen was collected.

There was an abundance of Cerithidea cingulata, Telescopium mauritsi and Geloina erosa on the forest floor. Local residents were collecting mud crab Scylla serrata using pods. The salinity of the creek water was $15 \mathrm{ppt}$.

Site 6: Ruku mangrove forest (Figure 1).

Located near Kg.Raja Dagang. The forest was mostly colonized by A. alba, Nypa fruticans and a few young Bruguiera. There were many Thalassina mounds with puddles in between. Walking in the forest was difficult as it was dense and had many aerial roots of Avicennia alba. The salinity of forest floor water was 5 ppt.

The mangrove fauna consisted of Sesarminae, Cerithidea quadrata (Plate 2), Neritina violacea, Fairbankia sp., Clithon aouleniensis, pulmonates Cassidula aurisfelis and Pythia scarabeus as well as the bivalve Geliona erosa (Table 1).

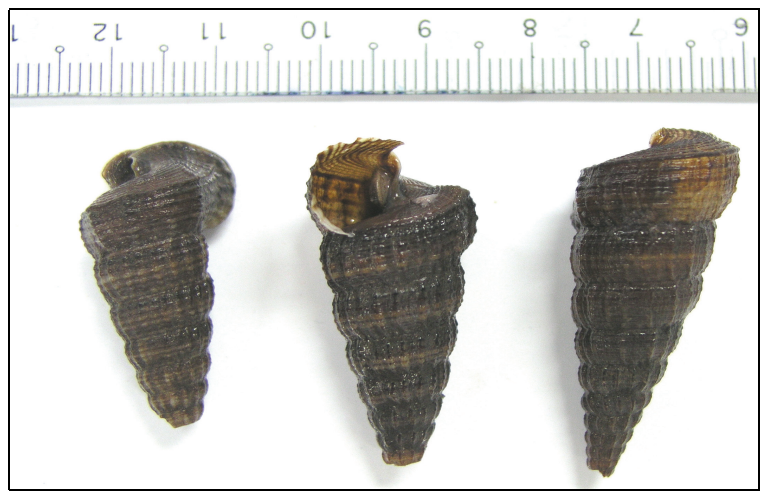

Plate 2. Cerithidea quadrata.

\section{Site 7: Kuala Sg. Melawi}

Kuala Sg. Melawi (Figure 2) is a small estuary where the connection to the sea had been temporarily blocked by a sand bar. Common vegetation at the mid and upper shore was mainly Nypa fruitcans, Hibiscus tiliaceus, Intsia bijuga and Casuarina equistifolia.
The macrobenthos was dominated by the gastropod Faunus ater (Plate 3) which occurred in the thousands on the sand-mud substrate near the mangroves (Table 1). Many specimens of Faunas ater had oysters encrusted on their shells. Other invertebrates observed were Uca annulipes, Perisesarma eumolpe (Plate 4), pea crab Dotilla sp. and Cerithidea cingulata.

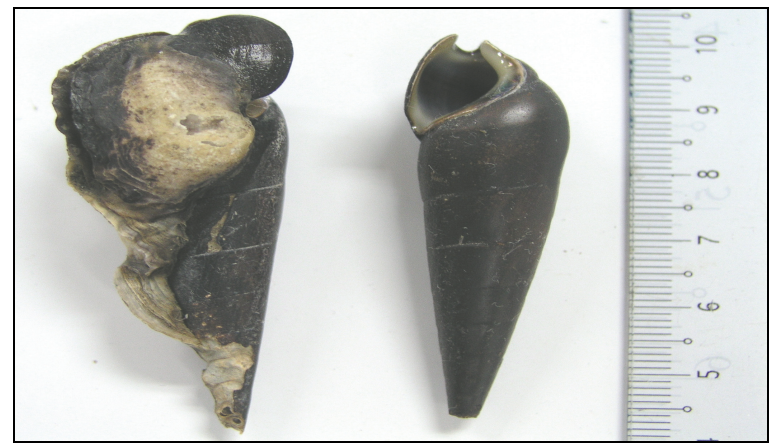

Plate 3. Specimens of the Faunus ater, left specimen with attached oyster.

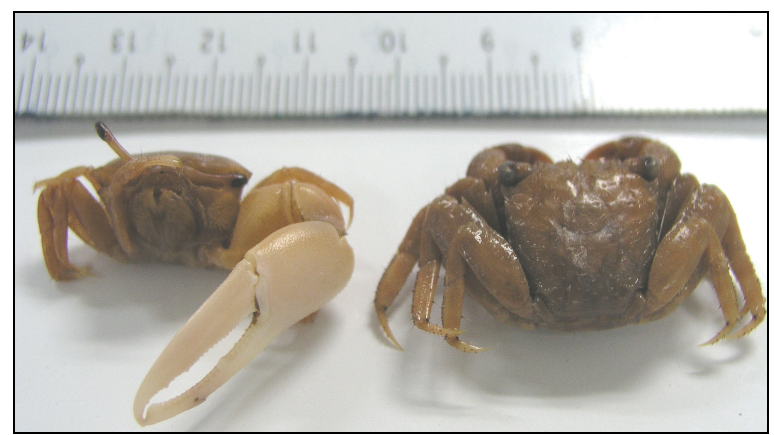

Plate 4. Uca annulipes (left) and Perisesarma sp.

Site 8: Kuala Sg. Kemasin (Figure2)

There was a clear water lagoon where construction of fish landing facilities was being carried out. The presence of Avicennia alba and few other mangrove species were noted on the shores of the lagoon.

The following plants were found on the sand ridge: Hibiscus tiliaceus, Casuarina equistifolia and Scaevola sericea. The creeper Thespecia (purple flowers) and Pandanus sp. were common on the beach side. There were many mangrove animals which included the following abundant ones: Faunas ater, Neritina violacea, Cassdula aurisfelis (Plate 5) C. oualeniensis (Plate 6), and the bivalves Ostrea cucullata, and Xenostrobus sp (Table 1). Many small fishes were observed in the clear waters of the lagoon. The salinity of the lagoon water was $21 \mathrm{ppt}$. 


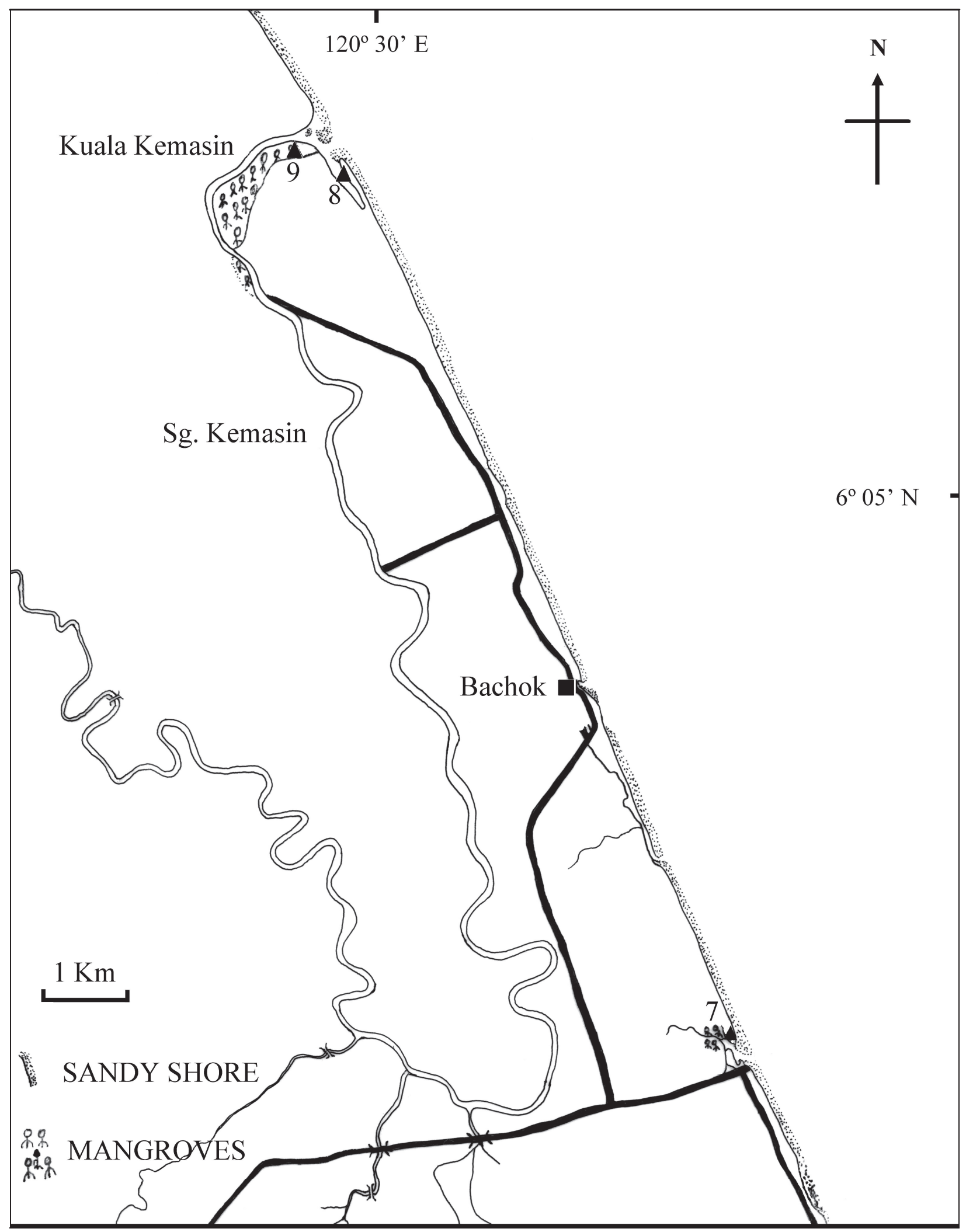

Figure 2. Distribution of mangrove forests in the estuary of Sg. Kemasin and Kuala Melawi, Kelantan. Sampling for macrofauna was carried out in Kuala Melawi (7) and Kuala Sg. Kemasin (8 and 9) during June 2008. 


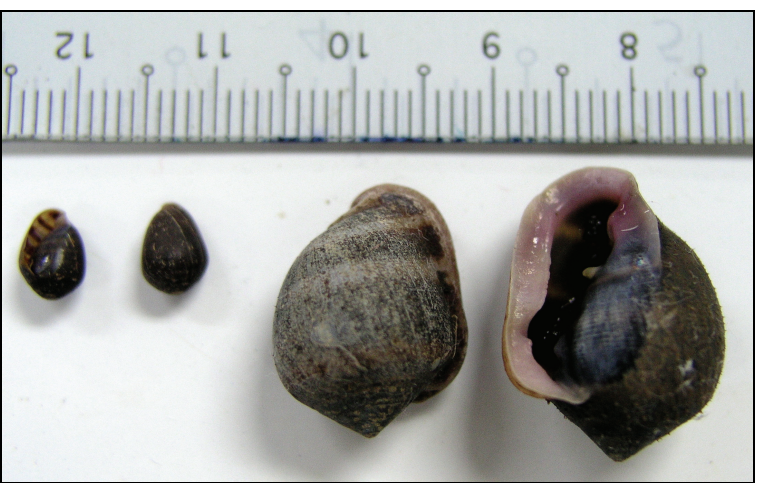

Plate 5. Pulmonates Melampus sp. (left) and Cassidula aurisfelis (right).

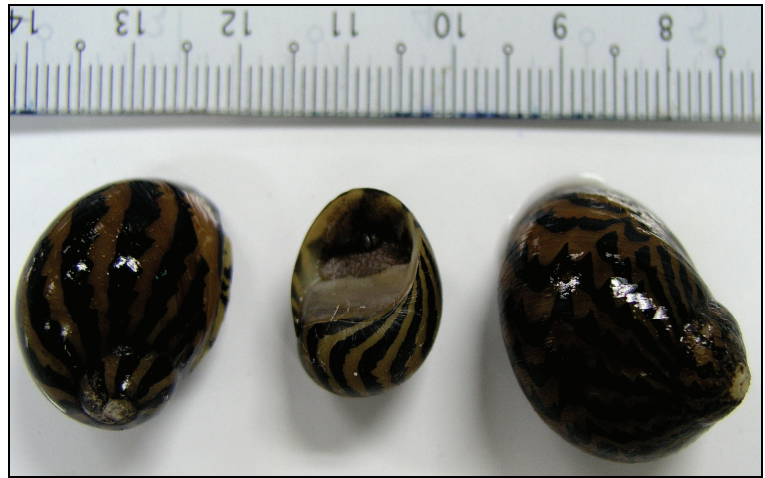

Plate 6. Specimens of Clithon aouleniensis.

Site 9: Kuala Sg. Kemasin (Figure 2)

The mangroves on the banks of the river have been cleared leaving one or two trees standing alone along the edge. It looks very dangerous as it is bound to be eroded unless embankments are constructed. The following invertebrates were collected from the substrate and tree trunks: Littoraria spp. Clithon oualensiensis, Telescopium telescopium and Neritina violacea (Table 1).

We visited the Fisheries Department, and then drove along a narrow road to prawn aquaculture ponds on the banks of the Kuala Kemasin. The land adjoining the river has been converted into ponds for culture of tiger prawns.

\section{DISCUSSIONS}

The east coast mangroves are estuarine in nature as they do not face the open sea like fringing mangroves of the west coast. As such mangroves only face mild wave action in estuaries. In view of the tidal range of less than one metre in Kelantan coast, the tidal currents do not show high velocities unlike in Port Klang area where the tidal range of 5 metres produces tidal currents with high velocities. We found large amounts of litter on the forest floor in Sg. Semerak which indicates that the litter has not been swept away by tidal currents. Large numbers of Neritina violacea, a detritus feeder, were found on decaying litter in Sites 1, 2, 36 and 8. The gastropod scraps food material from the surface of decaying leaves.

The fauna in Bachok mangroves and west coast mangroves in Kapar or Matang are very similar except for the abundance of a few species which were absent on the west coast (e.g. Faunus ater) or occurred in lesser numbers (e.g. Clithon oualeniensis). The gastropod, Faunus ater was very common in the estuarine sand-mudflats of Kuala $\mathrm{Sg}$ Melawi and Kuala Sg. Kemasin while another gastropod Clithon aouleniensis was common in sandmud substrates in several localities in Bachok.

Among the crustaceans, fiddler crabs were conspicuously not visible except for the occurrence of Uca annulipes in abundance on sand-mud flats at Kuala Melawi. The absence of fiddler crabs in Bachok mangroves may be attributed to the sandmud substrate which is preferred by $U$. annulipes but not by other fiddler crabs like $U$. rosea, $U$. triangularis, $U$. dussumieri and $U$. mani. The latter species preferred soft sediment substrates of the west coast mangroves [6]. Interestingly, Wong et al. [3] only found $U$. annulipes and $U$. forcipata in $\mathrm{Sg}$. Merang and Sg Setiu (Kelantan) while other fiddler crabs occurred further south in the mangrove shores of Kemaman and further south on the east coast. It appears that the substrate in Bachok mangroves consists of a mixture of coarse sand with less fine sediments such as silt and clay. There may be distinct differences between east and west coast mangroves in view of the physical differences between the coastal areas brought about by different tidal regimes.

The conservation of mangroves in Kelantan which was previously reported to cover 744 ha [4] is now believed to cover only 6 ha as reported by an official of the Forest Department, Kelantan. It appears there is no recognition for the ecological importance of mangroves in Kelantan, as elsewhere in much of the third world where mangroves are undervalued, overexploited, and poorly managed [7]. The importance of mangroves to humans, wildlife, fisheries and global carbon balance is paramount as recent scientific investigations reveal [8]. A similar unfortunate situation prevails in over-developed Singapore where only $1 \%$ of its original mangrove cover exists today [9].

Recent reviews on macrobenthos show their importance in mangrove vegetation structure and ecosystem function [10]. Sesarmid and ocypodid 
crabs assist in retaining forest products by processing organic matter, that is, by burying, macerating and ingestion of leaves and microalgal mats [11]. It is about time policy makers realized that mangroves are a vital habitat for many species of plants and animals [12]. These include mammals, birds, reptiles and insects which live in the tree canopy. Below the water, live epibionts such as sponges, algae and bivalves, while the substrata is home to polychaetes, molluscs, crustaceans, sipuncula and other invertebrates. In the creeks and estuaries, live young prawns, crabs and fishes. To ignore the existence of these living creatures is to ignore the livelihood of shallow water traditional fishermen who have been harvesting marine animals in a sustainable manner for thousands of years.

\section{ACKNOWLEDGEMENTS}

We gratefully acknowledge financial assistance of PJP research grant FS301/2008A from University of Malaya and IOES for logistic support. Mr. Teoh H. W. (UM) and Dr. Jeehan Jaafar (NUS) kindly identified the hermit crabs and gobiid fishes respectively. We appreciate the helpful comments of two anonymous referees.

\section{REFERENCES}

1. Gong, W.K., Ong, J.E. and Leong, Y.K. (1980). The mangroves of the east coast of Peninsular Malaysia. In: Coastal Resources of east coast Peninsular Malaysia (eds. Chua, T. E and Charles, J.K.) Universiti Sains Malaysia, Penang, pp. 28-57.

2. Malaysian Wetland Directory (1987). Department of Wildlife and National Parks, Peninsular Malaysia. Kuala Lumpur.

3. Wong T. M., Charles, J. K. and Khoo, T .T. (1980). Mangrove invertebrate resources of the east coast of Peninsular Malaysia. In: Coastal Resources of east coast Peninsular Malaysia (eds. Chua, T. E and Charles, J.K.), Universiti Sains Malaysia, Penang. Pp 58-94.

4. Forest Department, Kelantan (2009). Department of Forestry, Kelantan. Website information.

5. Latiff, A. (2005). Conservation and management of mangroves in Peninsular Malaysia. In Sustainable Management of Matang Mangroves: 100 years and beyond (Eds. Shaharuddin M I, M. Azahar, U. Razani, A B Kamaruzaman, K.L Lim, S. Rosli, M. S. Jalil and A Latiff). Forest Department Peninsular Malaysia, Kuala Lumpur.

6. Sasekumar, A. (1974). Distribution of mangrove fauna on a Malaysian mangrove shore. J. Anim Ecol 43: 51- 64.
7. Ewel, K.C., Twilley, R. R. and Ong, J. E. (1998). Different kinds of mangrove forests provide different goods and services. Global Ecol. Biogeogr Letters 7: 83-94.

8. Kristensen, E., Bouillon, S., Dittmar, T., Marchand, C. (2008). Organic carbon dynamics in mangrove ecosystems: A Review. Aquatic Botany 89: 201-219.

9. Liow, L.H. (2000). Mangrove conservation in Singapore: A physical or a psychological impossibility? Biodiversity and Conservation 9: 309-332.

10. Cannicci, S, Burrows, D., Fratini, S., Smith III, T.,Offenberg, J., Dahdouuh-Gubas, F. (2008). Faunal impact on vegetation structure and ecosystem function in mangrove forests: a review. Aquatic Botany 89: 186-200.

11. Kristensen, E. (2008). Mangrove crabs as ecosystem engineers; with emphasis on sediment processes. Journal of Sea Research 59: 30-43.

12. Nagelkerken, I, Blaber, S.J.M., Bouillon, S., Green, P., Haywood, M., Kirton, L.G., Meynecke, J.O., Pawlik, J., Penrose, S.M., Sasekumar, A., Somerfield, P.J. (2008). The habitat function of mangroves for terrestrial and marine life: A review. Aquatic Botany 89: 155185. 